Jurnal Keperawatan Silampari

Volume 3, Nomor 1, Desember 2019

e-ISSN :2581-1975

p-ISSN :2597-7482

DOI: https://doi.org/10.31539/jks.v3i1.771

\title{
PENGARUH ORIENTASI DENGAN METODE PERCEPTORSHIP DAN MIX STAFFING TERHADAP MUTU LAYANAN KEPERAWATAN
}

\author{
Yuli Yanti ${ }^{1}$, Muhammad Hadi ${ }^{2}$, Rohadi Haryanto ${ }^{3}$ \\ Program Magister Keperawatan, Universitas Muhammadiyah Jakarta ${ }^{1,2,3}$ \\ abizar.ikbal@gmail.com ${ }^{1}$
}

\begin{abstract}
ABSTRAK
Tujuan penelitian ini adalah untuk memperoleh gambaran mutu layanan keperawatan sebelum dan setelah dilakukan orientasi dengan metode preceptorship dan mix staffing di RSUD Pasar Minggu Jakarta Selatan 2018. Metode penelitian ini merupakan penelitian kuantitatif dengan jenis penelitian quasi experiment dengan rancangan pre dan post with control group design. Hasil penelitian menunjukkan secara statistik terdapat perbedaan antara mutu layanan keperawatan sebelum dan sesudah dilakukan intervensi orientasi metode preceptorship dan mix staffing $(\mathrm{p}<0,05)$. Hasil analisis juga menunjukkan terdapat perbedaan mutu layanan keperawatan pada kelompok kontrol dari pengamatan ke-1, ke-2, ke-3, dan ke-4 ( $p<0,05)$. Simpulan penelitian ini orientasi metode preceptorship dan mix staffing sangat potensial dalam meningkatkan mutu pelayanan keperawatan di rumah sakit.
\end{abstract}

Kata Kunci: Mix Staffing, Mutu Layanan Keperawatan, Preceptorship

\section{ABSTRACT}

The purpose of this study was to obtain a description of the quality of nursing services before and after orientation with the preceptorship and mix staffing methods at Pasar Minggu South Jakarta Hospital 2018. This research method is a quantitative study with a quasi-experimental research type with pre and post with control group design. The results showed that statistically there were differences between the quality of nursing services before and after the intervention intervention of the preceptorship and mix staffing methods $(p<0.05)$. The analysis also showed that there were differences in the quality of nursing services in the control group from the 1st, $2 \mathrm{nd}$, 3rd and 4th observations $(p<0.05)$. The conclusion of this research is the orientation of the preceptorship and mix staffing methods is very potential in improving the quality of nursing services in hospitals.

Keywords: Mix Staffing, Quality of Nursing Services, Preceptorship 


\section{PENDAHULUAN}

Program preceptorship digunakan sebagai alat sosialisasi dan orientasi, serta sebagai salah satu metode recruitment staf. Akses kepengetahuan organisasi dan praktik klinik dapat diprediksi oleh perawat baru, sehingga diskusi antara preceptor dan preceptee diperlukan untuk memberikan praktik terkini dalam pemberian asuhan keperawatan di rumah sakit atau instansi kesehatan yang lain, sehingga penting bagi manajer keperawatan mengelola tenaga keperawatan dengan baik sejak proses awal (Elley, SM, 2010).

Program preceptorship sudah mulai diterapkan dalam proses pembelajaran dimana program preceptorship ini bertujuan untuk membentuk peran dan tanggung jawab perawat yang professional dan berpengetahuan tinggi, dengan menunjukan sebuah pencapaian berupa memberikan perawatan yang aman, menunjukan akun tabilitas kerja, dapat dipercaya, menunjukan kemampuan dalam mengorganisasi perawatan pasien dan mampu berkomunikasi dengan baik terhadap pasien dan staf lainnya, preceptorship sehingga sangat membantu dalam proses transisi atau kesempatan untuk meningkatkan kompetensi keterampilan perawat baru untuk dapat mempersiapkan perawat baru memasuki dunia kerja dengan aman (Elley, SM, 2010).

Tak dapat dipungkiri bahwa perawat dan berbagai tugas serta tanggung jawab yang melekat padanya (nurse staffing) merupakan garda terdepan dalam sebuah rangkaian sistem layanan kesehatan. Ia menjadi bagian penting yang merepresentasi sekaligus menjadi tolak ukur dari kualitas sistem keorganisasian dan manajemen yang dimiliki oleh sebuah rumah sakit atau jasa layanan kesehatan lainnya. Bahkan, persepsi konsumen terhadap tingkat kualitas penyedia jasa layanan kesehatan sangat dipengaruhi oleh bagaimana tugas-tugas keperawatan di regulasi dan dijalankan. Oleh karenanya disamping aspek penting lain (seperti ketersediaan fasilitas dan teknologi medis) yang memadai, nurse staffing adalah salah satu hal utama yang perlu diperhatikan dengan seksama guna meningkatkan peluang keselamatan dan kesembuhan pasien (Eva, 2002).

Data yang diperoleh dari rumah sakit umum daerah Pasar Minggu belum baru akan menerapkan orientasi denga model preceptorship di awal tahun 2018 dengan SOP yang telah dibuat oleh RSUD Pasar Minggu desiminasi ilmu terkait preceptor sebelumnya sudah dilakukan peneliti pada saat aplikasi di RSUD pasar minggu hal ini di karenakan sistim orientasi yang dilakukan oleh pihak rumah sakit belum memiliki penilaian yang dilakukan oleh preceptor. Di RSUD sendiri tidak hanya perawat baru yang harus bisa beradaptasi tetapi perawat lama juga terkadang sering di pindahkan keruangan ruangan yang membutuhkan terkait kekurangan tenaga sehingga perlu orientasi kembali terhadap ruangan, bedasarkan fenaomena tersebut peneliti tertarik untuk mengambil penelitian terkait "pengaruh orientasi dengan metode preceptorship dan mix staffing terhadap peningkatan mutu layanan keperawatan di RSUD Pasar Minggu" dalam penelitian ini peneliti ingin melihat apakah dengan metode tersebut dapat mempengaruhi mutu layanan keperawatan dalam hal ini tingkat kepuasan pasien dan keselamatan psien terkait sistem orientasi menggunakan preceptor dan mix staffing, berdasarkan teori yang didapat peneliti idealnya satu orang preceptor membimbing satu perawat agar bisa mencapai target kompetensi yang ada di rumah sakit, namun penerapan di rumah sakit preceptor membimbing lebih dari satu perawat (Morton Cooper A, Palmer A, 2000). 


\section{METODE PENELITIAN}

Penelitian ini merupakan penelitian kuantitatif dengan jenis penelitian quasi experiment dengan rancangan pre dan post with control group design. Pada kelompok intervensi sebelum dilakukan metode preceptorship dan mix staffing akan diukur terlebih dahulu mutu layanan keperawatan mealui kepuasan pasien. Setelah itu dilakukan persamaan persepsi tentang preceptorship dengan desiminasi dan memberikan modul kepada ketua tim dan penanggung jawab. Setelah itu kepala ruangan dan peneliti menyusun jadwal shift perawat dengan melakukan mix staffing dilihat dari pendidikan dan lama kerja. Setelah tersusun maka dilakukan penelitian menilai pengaruh mutu layanan keperawatan setelah di lakukan preceptorship dan mix staffing yang dilakukan selama 3 minggu dengan jumlah responden sebelum dilakukan perlakukan pada perawat sebanyak 13 responden dan setelah dilakukan sebanyak 13 responden selama 3 kali dengan jumlah sampel keseluruhan 52 responden maka akan pengukuran mutu layanan keperawatan melalui kuisioner kepuasan pasien maka akan dilakukan. Data diolah menggunakan komputer. Kaji etik dilakukan oleh Komite Etik Riset Fakultas Ilmu Keperawatan Universitas Muhammadiyah Jakarta.

\section{HASIL PENELITIAN}

Tabel. 1

Rata - Rata Nilai Mean dan Standar

Deviasi Berdasarkan Usia (N=104)

\begin{tabular}{clllccc}
\hline Variabel & Kelompok & $\mathrm{N}$ & Mean & SD & $95 \%$ CI & Min- Maks \\
\hline Usia (dalam tahun) & Intervensi & 52 & 50,08 & 17,25 & $45,28-54,88$ & $20-79$ \\
& Kontro 1 & 52 & 47,90 & 15,72 & $43,53-52,28$ & $18-79$ \\
\hline
\end{tabular}

Hasil analisis data pada tabel 1 menggambarkan rerata usia kelompok intervensi lebih tua (mean 50,08 dan SD 17,25) dibandingkan dengan kelompok kontrol (mean 47,90 dan SD 15,72). Rentang usia responden kedua kelompok sangat lebar dengan usia termuda pada kelompok intervensi adalah 20 tahun dan usia termuda pada kelompok kontrol 18 tahun dengan usia tertua kedua kelompok mencapai 79 tahun.

Tabel. 2

Distribusi Jenis Kelamin dan Status Jaminan Responden (N=104)

\begin{tabular}{lcccc}
\hline Variabel & Jumlah & Frekuensi(\%) & Jumlah & Frekuensi(\%) \\
\hline Jenis Kelamin & & & & \\
Laki-laki & 20 & 58,5 & 17 & 32,7 \\
Perempuan & 32 & 61,5 & 35 & 67,3 \\
Status Jaminan Sosial & & & & 100 \\
BPJS & 52 & 100 & 52 & 0 \\
Non BPJS & 0 & 0 & 0 & \\
\hline
\end{tabular}

Dari tabel 2 diatas dapat dilihat bahwa mayoritas responden dikedua kelompok adalah perempuan dengan $61,5 \%$ pada kelompok intervensi dan 67,3\% pada kelompok kontrol dan seluruh responden yang mengikuti penelitian ini merupakan pasien dengan jaminan sosial BPJS. 
Tabel. 3

Hasil Analisis Perbedaan Mutu Layanan Keperawatan Pengamatan Sebelum dan Setelah Intervensi Orientasi Metode Preceptorship dan Mix Staffing terhadap Mutu Layanan Keperawatan

\begin{tabular}{lcrccc}
\hline \multicolumn{1}{c}{ Kelompok } & Mean & SD & Mean Difference & 95\%CI & P-Value \\
\hline \multicolumn{7}{l}{ Pengamatan Ke-1 } & Sebelum & Intervensi & & & \\
Intervensi & 67,92 & 8,40 & 1,39 & $-7,03-4,26$ & 0,62 \\
Kontrol & 69,31 & 5,17 & & & \\
\hline \multicolumn{7}{l}{ Pengamatan Ke-4 } & Setelah Intervensi & & & \\
Intervensi & 92,23 & 1,74 & 18,54 & $17,38-19,70$ & 0,00 \\
Kontrol & 73,69 & 1,03 & & & \\
\hline
\end{tabular}

Hasil analisis menunjukkan bahwa secara statistik pada kelompok intervensi dan kontrol sebelum dilakukan orientasi preceptorship dan mix staffing tidak terdapat perbedaan mutu layanan keperawatan pada kedua kelompok intervensi dan kelompok kontrol ( $p>0,05)$. Berbeda dengan pengamatan ke-1 (pre-intervensi) dimana tidak terdapat perbedaan antara kedua kelompok. Sedangkan hasil analisis pada mutu layanan setelah dilakukan intervensi preceptorship dan mix staffing pada pengamatan ke-4. Nilai mean pada kelompok intervensi lebih besar dibandingkan dengan kelompok kontrol. Pada pengamatan ke-4 sebesar 9,23. Nilai $\mathrm{p}<0,05$ pada pengamatan ke-1 sampai dengan ke-4 menunjukkan bahwa secara statistik terdapat perbedaan mutu layanan keperawatan antara kelompok yang diberi intervensi orientasi metode preceptorship dan mix staffing dengan kelompok kontrol.

Tabel. 4

Hasil Analisis Selisih Uji Beda Mean pada Kelompok Intervesi dan Kelompok Kontrol pada Mutu Layanan Keperawatan Orientasi Metode Preceptorship dan Mix staffing

\begin{tabular}{|c|c|c|c|c|c|}
\hline Kelompok & Mean & SD & Mean Difference & $95 \% \mathrm{CI}$ & P-Value \\
\hline \multicolumn{6}{|c|}{ Pengamatan Ke-1 sebelum intervensi } \\
\hline Intervensi & 24.31 & 8.17 & 19.92 & $14.26-25.59$ & 0,00 \\
\hline Kontrol & 4.38 & 5,59 & & & \\
\hline
\end{tabular}

Hasil analisis menunjukkan bahwa secara statistik uji selisih pada kedua kelompok sebelum dan sesudah dilakukan orientasi preceptorship dan mix staffing di peroleh data nilai mean kelompok intervensi lebih besar dibandingkan dengan kelompok kontrol. Nilai p 0,00 kelompok intervensi dan kelompok kontrol ini menunjukkan bahwa secara statistik terdapat perbedaan mutu layanan keperawatan antara kelompok yang diberi intervensi orientasi metode preceptorship dan mix staffing dengan kelompok kontrol.

Tabel. 5

Hasil Analisis Perbedaan Mutu Layanan Keperawatan Sebelum dan Setelah Intervensi Orientasi Metode Preceptorship dan Mix staffing

\begin{tabular}{lrcccc}
\hline \multicolumn{1}{c}{ Penilaian Mutu } & Mean & SD & Mean Difference & 95\%CI & P-Value \\
Kelompok Intervensi & & & & & \\
Pengamatan ke-1 & 67,92 & 8,40 & 24,31 & $19,37-29,24$ & 0,000 \\
Pengamatan ke-4 & 92,23 & 1,74 & & & \\
\hline
\end{tabular}


Kelompok Kontrol

Pengamatan ke-1

Pengamatan ke-4

$69,31 \quad 5,17$

$73,69 \quad 1,03$

4,39

$1,01-7,76 \quad 0,015$

Tabel 5 menunjukkan bahwa secara statistik terdapat perbedaan antara mutu layanan keperawatan sebelum dan sesudah dilakukan intervensi orientasi metode preceptorship dan mix staffing dengan nilai $\mathrm{p} 0,000$ ( $\mathrm{p}<0,05)$. Peningkatan ini menunjukkan bahwa nilai mutu layanan meningkat pada kelompok intervensi ynag berarti bahwa mutu layanan keperawatan kelompok intervensi semakin baik.

Hasil analisis juga menunjukkan terdapat perbedaan mutu layanan keperawatan pada kelompok kontrol dari pengamatan ke-4. Namun, meskipun secara statistik tampak perbedaan di pengamatan $(\mathrm{p}<0,05)$, selisih rerata mutu antara pengamatan pertama dengan pengamatan selanjutnya (ke-1 sampai dengan ke-4), tampak menurun pada kelompok yang tidak diberi intervensi orientasi metode preceptorship dan mix staffing.

Tabel. 6

Analisis Uji Homogenitas Levene Skor Mutu Layanan Keperawatan

\begin{tabular}{lcc}
\hline Waktu & Nilai Uji Levene & P-value \\
\hline Pengamatan ke-1 (Pre Intervensi) & 2,47 & 0,13 \\
Pengamatan ke-2 & 1,70 & 0,21 \\
Pengamatan ke-3 & 2,47 & 0,13 \\
Pengamatan ke-4 & $\underline{2,15}$ & $\underline{0,16}$ \\
\hline
\end{tabular}

Menunjukkan bahwa variabel mutu layanan keperawatan dari minggu ke-1 sampai ke-4 memiliki nilai $p>0,05$ yang berarti sebaran varian skor kepuasan pasien tidak berbeda pada kedua kelompok intervensi dan kontrol.

Tabel. 7

Parameter Estimates Mutu Layanan Keperawatan

\begin{tabular}{clcc}
\hline Variabel Dependen & Parameter & P-value & Partial Eta Squared \\
\hline \multirow{2}{*}{ Pengamatan ke-1 } & Intercept & 0,000 & 0,982 \\
& Intervensi & 0,617 & 0,011 \\
& Kontrol & - & - \\
& Intercept & 0,000 & 0,998 \\
Pengamatan ke-2 & Intervensi & 0,000 & 0,640 \\
& Kontrol & - & - \\
& Intercept & 0,000 & 0,999 \\
Pengamatan ke-3 & Intervensi & 0,000 & 0,963 \\
& Kontrol & - & - \\
& Intercept & 0,000 & 0,999 \\
Pengamatan ke-4 & Intervensi & 0,000 & 0,979 \\
& Kontrol & - & - \\
\hline
\end{tabular}

Hasil tes pada tabel 7 menunjukkan ada kontrol. Nilai partial eta squared perbedaan rerata total nilai mutu pelayanan pengamatan ke-4 sebesar 0,979. keperawatan pada kelompok intervensi. 


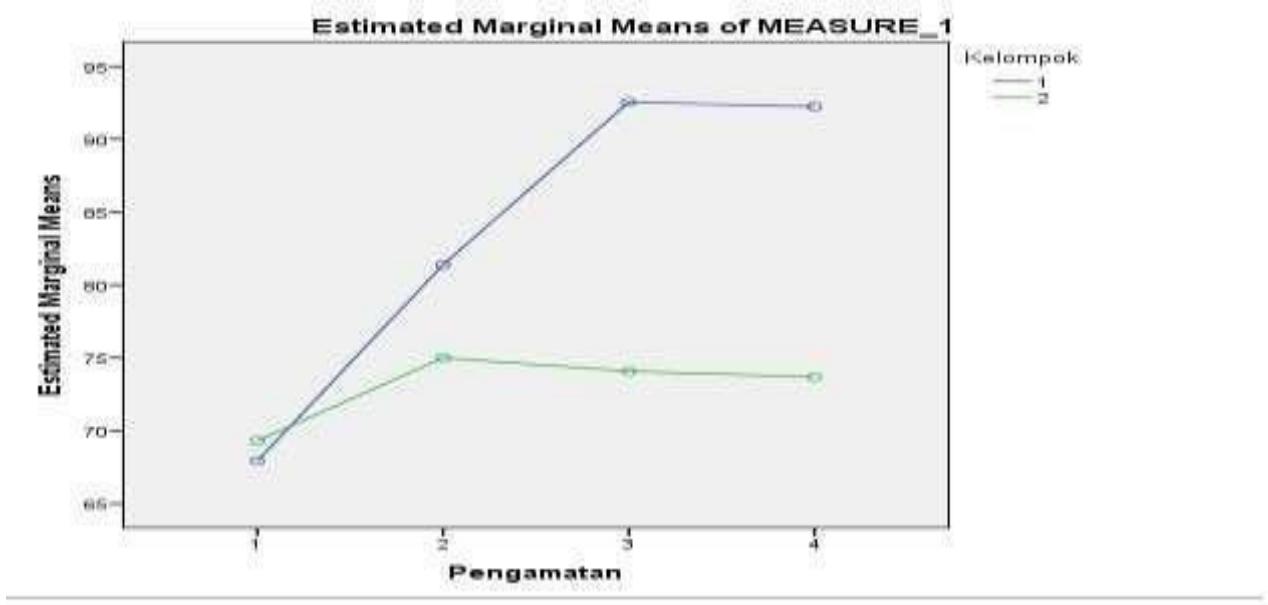

Gambar. 1

Gambaran Kenaikan Rata-Rata Mutu Pelayanan Keperawatan pada Kenaikan Rata-Rata Y Tiap Pengukuran antar Kelas Kelompok

Grafik rerata mutu pelayanan keperawatan antara kelompok yang diterapkan orientasi metode preceptorship dan mix staffing dengan kontrol menunjukkan perbedaan yang bermakna. Grafik diatas menunjukkan bahwa mutu layanan keperawatan pada kelompok intervensi cenderung mengalami kenaikan dari pengamatan ke-1 hingga ke-3 dan sedikit menurun di pengamatan ke-4. Berbanding terbalik dengan kelompok intervensi, rerata mutu pelayanan keperawatan pada kelompok kontrol hanya mengalami kenaikan di pengamatan ke- 2 dan selanjutnya mengalami penurunan pada pengamatan ke-3 dan ke-4. Hasil analisis diatas menunjukkan bahwa orientasi metode preceptorship dan mix staffing sangat potensial dalam meningkatkan mutu pelayanan keperawatan di rumah sakit.

\section{PEMBAHASAN}

Masyarakat atau pasien melihat pelayanan kesehatan yang bermutu sebagai suatu pelayanan kesehatan yang dapat memenuhi kebutuhan yang dirasakannya dan diselenggarakan dengan cara yang sopan dan santun, tepat waktu, tanggap dan mampu menyembuhkan keluhannya serta mencegah berkembangnya atau meluasnya penyakit. Pandangan pasien ini sangat penting karena pasien yang merasa puas akan mematuhi pengobatan dan mau datang berobat kembali.

Faktor penentu tingkat kepuasan pelanggan atau konsumen juga dipengaruhi oleh karakteristik dari konsumen tersebut yang merupakan ciri-ciri seseorang atau kekhasan seseorang yang membedakan seorang yang satu dengan yang lain. Karakteristik tersebut berupa nama, umur, jenis kelamin, jaminan dan lain- lain (Sangadji \& Sopiah, 2013).

Dalam penelitian ini usia mayoritas responden di RSUD Pasar Minggu Jakarta Selatan ruang rawat inap lantai 11 dan 9 adalah usia tua penelitian ini sejalan dengan penelitian yang dilakukan oleh Gunarsa (2008) mengungkapkan bahwa bertambahnya umur seseorang dapat berpengaruh pada kesehatannya, dimana terjadi kemunduran struktur dan fungsi organ, sehingga masyarakat yang berusia lebih tua cenderung lebih banyak memanfaatkan pelayanan kesehatan dibandingkan dengan usia muda.

Namun bila dikaitkan dengan kepuasan pasien dilihat dari 5 dimensi kualitas pelayanan yaitu, (reability, tangibles, assurance, responsiveness, dan empathy) pada penelitian ini di peroleh hasil usia tua cenderung menyatakan puas terhadap mutu layan keperawatan. Penelitian ini sejalan dengan penelitan yang dilakukan oleh Gunarsa 
(2008) menyatakan pasien usia tua cenderung lebih cepat puas dibandingkan usia muda. Hal ini karena orang usia tua umumnya lebih bersifat terbuka, sehingga pasien usia tua tuntutan dan harapannya lebih rendah dari pasien usia muda sehingga pasien usia tua cendrung lebih cepat puas di bandikan dengan pasien usia muda.

Dengan demikian dapat disimpulkan bahwa tingkat kepuasan pasien bukan hanya tergantung dari usia melainkan tergantung pada kemampuan penyedia jasa dalam memenuhi harapan pelanggan secara konsisten.

Selain usia, karakteristik jenis kelamin juga di lihat dalam penelitian ini dimana dari hasil penelita ini rerata jenis kelamin pasien yang da di ruang rawat inap lantai 11 dan 9 dari kedua kelompok yaitu berjenis kelamin wanita menyatakan puas ini dinilai dari 5 dimensi kualitas pelayanan yaitu (reability, tangibles, assurance, responsiveness dan empathy).

Dilihat dari penelitian sebelumnya, jenis kelamin memiliki pengaruh pada pandangan terhadap jasa yang diberikan. Perempuan lebih banyak melihat penampilan secara detail, sementara laki-laki tidak mengindahkan hal tersebut. Cara mengelola hubungan untuk kaum laki-laki, mereka cenderung lebih cuek dengan hal yang dikemukakan oleh perempuan, karena itu mereka dianggap lebih fleksibel dibandingkan perempuan (Gunarsa, 2008). Berbeda dengan peneliti yang dilakukan oleh Dolinsky mengemukakan bahwa persepsi dan reaksi terhadap gangguan sakit dipengaruhi oleh sex, ras, pendidikan, kelas ekonomi dan latar belakang budaya. Dari pernyataan tersebut antara pria dan wanita akan relatif sama dalam merasakan kepuasan (Dolinsky, 2006). Selain usia dan jenis kelamin, status jaminan juga menjadi karakteristik penelitian ini dimana di peroleh hasil seluruh responden dalam penelitian ini mayoritas responden memiliki status jaminan BPJS. Mayoritas pasien BPJS mengatakan puas dengan mutu layanan keperawatan di RSUD Pasar Minggu. Bila dilihat dari segi fasilitas untuk kelas 3 , terlihat ruangan dan fasilitasnya lengkap dan nyaman.

Pada pasien dengan jaminan kesehatan asuransi lainnya apabila dikenakan iuran tambahan, biaya yang dibebankan tidak memberatkan. Berbeda dengan pasien yang menggunakan pembiayaan jamkesmas, rumah sakit tidak diperbolehkan untuk mengambil iuran biaya tambahan. Oleh karena itu pasien merasa mendapatkan pelayanan sesuai kebutuhannya tanpa membayar sehingga mereka mencapai kepuasan sendiri terhadapnya. Hal ini berarti rumah sakit mempunyai komitmen memberikan pelayanan yang terbaik terhadap pelanggannya sehingga pasien akan merasa puas dengan pelayanan keperawatan.

\section{Efektifitas Mutu Layanan Keperawatan Sebelum dan Sesuadah Intervensi Metode Preceptorship dan Mix staffing}

Sebelum melakukkan orientasi preceptorship dan mixstafing peneliti berdiskusi terlebih dahulu dengan kepala ruangan untuk menentukan preceptor dimana si preceptor ini nantinya harus mampu menguasai lima kompetensi yang terdapat pada kerangka teori dalam penelitian ini yaitu preceptor harus mampu berkolaborasi dengan preceptee, mengenal karakter individu prcepte, mampu mefasilitasi pembelajaran dimana sesuai dengan modul yang diberikan peneliti sebelum dilakukan metode ini, mampu melakukan praktek profesional, dan mampu penguasaan terhadap tugasnya sedangkan mix staffing dalam penelitian ini membagi tim sesuai dengan latar belakang pendidikan.

Dari hasil penelitian yang dilakukan di RSUD Pasar Minggu diperoleh bahwa ada pengaruh intervensi terhadap mutu layanan keperawatan sebelum dan sesudah dilakukan metode preceptorship dan mix staffing. Dapat dilihat bahwasanya terlihat 
perbedaan yang signifikan dari kedua kelompok dimana kelompok yang dilakukan intervensi cenderung lebih meningkat mutu layanan keperawatannya dibandingkan dengan kelompok kontrol $(\mathrm{p}<0,05)$. Dalam hal ini dapat terlihat bahwasanya metode orientasi preceptorship dan mix staffing efektif dilakukan dalam meningkatkan mutu pelayanan karena terjadi peningkatan dari minggu keminggu pengamatan. Peningkatan mutu keperawatan diukur melalui 5 dimensi kualitas pelayanan yaitu (reability, tangibles, assurance, responsiveness, dan empathy). Dari hasil tersebut terlihat bahwa kepuasan pasien meningkat terhadap kemampuan perawat dalam reability, tangibles, assurance, responsiveness, dan empathy.

Bila dilihat dari teori, preceptorship merupakan metode pengajaran dan pembelajaran kepada perawat sebagai model perannya. Preceptorship bersifat formal, disampaikan secara perseorangan dan individual dalam waktu yang sudah ditentukan sebelumnya antara perawat yang berpengalaman (preceptor) dengan perawat baru (preceptee) yang didesain untuk membantu perawat baru untuk menyesuaikan diri dengan baik dan menjalankan tugas yang baru sebagai seorang perawat (CNA, 2004). Sedangkan untuk mix staffing itu sendiri adalah berasal dari kata staffing dimana fungsi manajemen yang melakukan penarikan, penyeleksian, pengembangan dan penggunaan Sumber Daya Manusia (SDM) untuk pencapaian tujuan organisasi secara efektif dan efisien.

Berdasarkan fakta yang juga dibuktikan oleh nurse preceptor program builder (2007) mengatakan bahwa metode tersebut sangat membantu medorong perawat untuk bergerak meningkatkan keterampilannya dan membantu mereka menemukan beberapa inovasi untuk meningkatkan profesionalisme. Selain itu juga sesuai dengan teori Federal (2008) yang menyatakan seorang individu yang berpengalaman akan memberi dorongan, nasihat, dan dukungan kepada seorang rekan yang kurang berpengalaman, dengan tujuan membantu belajar secara intensif. Menurut Mamchur dan Myrick (2003) mengatakan bahwa koordinator dari program preceptorship penting mengenali konflik yang mungkin timbul, dimana sumber utama dari konflik pada pekerjaan berhubungan dengan tempat bekerja ini bisa berasal dari situasi dimana seseorang harus melakukan pemilihan antara dua tuntutan atau harapan yang saling bersaing (Dubrin, 2009). Bila preceptor tidak dapat memahami kedaan tersebut maka kesulitan dalam melakukan kolaborasi.

Dari pembahasan tersebut dapat di gambarkan dalam skema sebagai berikut: terganggu sehingga dapat mempengaruhi mutu layanan keperawatan. Berdasarkan penelitian yang dikaitkan dengan teori dan penelitian sebelumnya dapat di tarik kesimpulan metode perceptorship dan mix staffing akan meningkatkan mutu pelayanan keperawatan tergantung dari si preceptor menguasai lima kompetensi dimana seorang preceptor, mampu menguasai kompetensi tersebut maka akan mempengaruhi mutu layanan keperawatan. Sebaliknya ketidak mampuan preceptor dalam melaksanakan 5 kompetensi tersebut akan meningkatkan beban preceptee dan mebuat preceptee dalam melaksanakan pekerjaannya sehingga dapat mempengaruhi mutu layanan keperawatan.

Berdasarkan penelitian yang dikaitkan dengan teori dan penelitian sebelumnya dapat di tarik kesimpulan metode perceptorship dan mix staffing akan meningkatkan mutu pelayanan keperawatan tergantung dari si preceptor menguasai lima kompetensi dimana seorang preceptor, mampu menguasai kompetensi tersebut maka akan mempengaruhi mutu layanan keperawatan. Sebaliknya ketidakmampuan preceptor dalam melaksanakan 5 kompetensi tersebut akan meningkatkan beban preceptee dan 
mebuat preceptee dalam melaksanakan pekerjaannya sehingga dapat mempengaruhi mutu layanan keperawatan.

\section{SIMPULAN}

Karakteristik responden pada penelitian ini rerata usia responden termasuk usia tua dengan jenis kelamin terbanyak adalah wanita dan status jaminan BPJS terdapat perbedaan mutu layanan keperawatan sebelum dilakukan intervensi pada kedua kelompok dimana dilihat dari kepuasan pasien kelompok kontrol lebih tinggi di bandingkan kelompok intervensi Pengaruh mutu pelayanan keperawatan selama setelah diterapkan orientasi model preceptorship dan mix staffing secara statistik terdapat pengaruh mutu layanan keperawatan antara kelompok yang diberi intervensi orientasi metode preceptorship dan mix staffing dengan kelompok kontrol.

Efektifitas orientasi model preceptorship dan mix staffing terhadap mutu pelayanan keperawatan di RSUD Pasar Minggu Jakarta Selatan Hasil analisis menunjukkan bahwa orientasi metode preceptorship dan mix staffing sangat potensial dalam meningkatkan mutu pelayanan keperawatan.

\section{SARAN}

\section{Bagi Rumah sakit}

Rumah Sakit memberikan kesempatan kepada perawat untuk mengikuti pelatihan preceptorship sampai mendapatkan sertifikat sehingga dapat menerapkan program orientasi dengan metode preceptorship. Dalam penempatan perawat pada setiap shift dalam tim perlu dipertimbangkan pendidikan perawat dengan cara dilakukan mix staffing sehingga dapat memperkuat sistem preceptorship di RSUD pasar minggu Jakarta selatan.

\section{Bagi Keilmuan}

preceptorship dan mix staffing telah terbukti mampu memberikan dampak pada perubahan mutu pelayanan keperawatan dalam meningkatkan kepuasan pasien. Hasil penelitian ini diharapkan dapat dijadikan sumber informasi bagi keperawatan terutama manajemen keperawatan guna peningkatan mutu pelayanan keperawatan guna meningkatkan kepuasan pasien terhadap layanan keperawatan.

\section{Bagi Penelitian selanjutnya}

Hasil penelitian ini dapat dijadikan data awal dalam menentukan kebijakan penerapan preceptorship dan mix staffing untuk meningkatkan mutu layanan keperawatan, peneliti selanjutnya juga perlu menambahkan lama waktu penelitian serta dapat dilakukan di rumah sakit yang berbeda dengan karakteristik yang sama sehingga akan terlihat lama waktu yang dibutuhkan dalam pelaksanaan preceptorship dan mix staffing mencapai titik optimal dan menjadidasar untuk pelaksanaan penilaian mutu layanan keperawatan 


\section{DAFTAR PUSTAKA}

CNA. (2004). Achieving Excellence. Ottawa: Author
Dolinsky
C.,
(2006).
Breast
Cancer:
The
Basic. http://www.oncolink.com/types/article.cfm?c=3\&s=5\&ss=33\&id=8320.

Dubrin (2009). The Complete Ideal's Guides; Leadership. Edisi Kedua. Jakarta: Prenada Media Group

Elley, S. M. (2010). The power of Preceptorship. Dasadur dari http://www.mjournal.com/ journal of nursing/ the power of preceptorship_2. htm pada tanggal 15 Maret 2018 pk.20.30 wib

Federal Aviation Administration. (2008). Best Practices for Mentoring in Flight Instruction

Gunarsa \& Singgih. (2008). Psikologi Perawatan. Jakarta: Gunung Mulia

Mamchur, \& Myrick. (2003). In C. N. Association, Achieving Excelence. Ottawa.

Morton-Cooper A, Palmer A. (2000). Mentoring, Preceptorship and Clinical Supervision (Second Edition). Blackwell Science: Oxford

Nurse Preceptor Program Builder. (2007). What is A Preceptorship (Second Edition). HCPro

Sangadji, E. M., \& Sopiah. (2013). Consumer Behavior: Perilaku Konsumen dan Strategi Pemasaran Jilid 2. Jakarta: Erlangga 